\title{
An explanation of the educational structure of occupations
}

Citation for published version (APA):

Beekman, T. B. J., Dekker, R., de Grip, A., \& Heijke, J. A. M. (1989). An explanation of the educational structure of occupations. Researchcentrum voor Onderwijs en Arbeidsmarkt, Faculteit der Economische Wetenschappen. ROA Working Papers No. 3E https://doi.org/10.26481/umarow.198903E

Document status and date:

Published: 01/01/1989

DOI:

10.26481/umarow.198903E

Document Version:

Publisher's PDF, also known as Version of record

\section{Please check the document version of this publication:}

- A submitted manuscript is the version of the article upon submission and before peer-review. There can be important differences between the submitted version and the official published version of record.

People interested in the research are advised to contact the author for the final version of the publication, or visit the DOI to the publisher's website.

- The final author version and the galley proof are versions of the publication after peer review.

- The final published version features the final layout of the paper including the volume, issue and page numbers.

Link to publication

\footnotetext{
General rights rights.

- You may freely distribute the URL identifying the publication in the public portal. please follow below link for the End User Agreement:

www.umlib.nl/taverne-license

Take down policy

If you believe that this document breaches copyright please contact us at:

repository@maastrichtuniversity.nl

providing details and we will investigate your claim.
}

Copyright and moral rights for the publications made accessible in the public portal are retained by the authors and/or other copyright owners and it is a condition of accessing publications that users recognise and abide by the legal requirements associated with these

- Users may download and print one copy of any publication from the public portal for the purpose of private study or research.

- You may not further distribute the material or use it for any profit-making activity or commercial gain

If the publication is distributed under the terms of Article $25 \mathrm{fa}$ of the Dutch Copyright Act, indicated by the "Taverne" license above, 
AN EXPLANATION OF THE EDUCATIONAL

STRUCTURE OF OCCUPATIONS

ROA-W-1989/3E

Th.B.J. Beekman, R.J.P. Dekker, A. de Grip, J.A.M. Heijke

RESEARCH CENTRE FOR EDUCATION AND LABOUR MARKET

Faculty of Economic Sciences

Rijksuniversiteit Limburg

Maastricht, november 1989 
CIP-GEGEVENS KONINKLIJKE BIBLIOTHEEK, DEN HAAG

Explanation

An explanation of the educational structure of occupations / Th.B.J. Beekman ... [et al.].- Maastricht : Research Centre for Education and Labour Market, Faculty of Economic Sciences, Rijksuniversiteit Limburg. - (Rapport I Researchcentrum voor Onderwijs en Arbeidsmarkt, ISSN 0922-8098; 1989/3E)

Vert. van: Een verklaring van de opleidingenstructuur van beroepen.Maastricht : Researchcentrum voor Onderwijs en Arbeidsmarkt, Faculteit der Economische Wetenschappen, Rijksuniversiteit Limburg, 1989. - (Rapport I Researchcentrum voor Onderwijs en Arbeidsmarkt; 1989/30.

Met 1it. opg.

ISBN 90-5321-028-8

SISO 487 UDC $371.2: 377$

Trefw.: beroepsonderwijs 


\section{CONTENTS}

Page

SUMMARY

ACKNOWLEDGEMENT

1. INTRODUCTION

2. THE EDUCATIONAL MODEL

2.1. Classification of types of education and occupations

2.2. Technological development and displacement

3. THE ECONOMETRIC SPECIFICATION OF THE MODEL

3.2. Employment shares by level of education

3.3. Employment shares by educational discipline

4. THE ESTIMATION RESULTS 11

4.1. Estimation results by level of education 11

4.2. Estimation results by discipline 
This working document specifies and estimates a model intended to explain the educational structure of employment in occupational classes within industrial sectors. The model developed is meant as a tool for drawing up medium-term forecasts of the demand for manpower with a certain education. We will specify the educational model by defining each occupation's share in the employment of an industrial sector. The employment shares of a type of education in the occupations within an industrial sector are explained in two steps. The first step serves to explain the shares of levels of education by occupation and industrial sector, the explanatory factors being the substitution, or displacement, due to shifts in the supply and diffusion of technological developments, as expressed in the capital intensity and the degree of automation. In the second step, the shares of the various disciplines within a level of education in the employment are explained by occupation and industrial sector. 
ACKNOWLEDGEMENT

This study has been carried out within the framework of a research assignment stretching over several years, granted by the Ministry of Education and Sciences to the Research Centre for Education and Labour Market. The assignment is to develop an information system with respect to the relation between education and labour market, which is to serve as a guidance for the study and occupational choices of students in secondary and higher education.

The investigation reported on here represents an intermediary stage in the construction of the information system on education and labour market. The objective of the investigation was to make a model of the educational structure of occupations in industrial sectors.

The research was carried out under the supervision of Professor J.A.M. Heijke and Dr A. de Grip by Drs Th.B.J. Beekman jointly with Drs R.J.P. Dekker. The finishing of the estimation was taken care of by drs H.M.M. Peeters. 
1. INTRODUCTION

This working document specifies and estimates a model intended to explain the educational structure of employment in occupational classes within industrial sectors. The model is to serve as a tool for drawing up mediumterm forecasts of the demand for manpower with a certain education.

The educational model fits into a larger framework, namely, the construction of a model for medium-term forecasts as part of the information system on education and labour market being developed by the Research Centre for Education and Labour Market (ROA) (see Heijke 1986). At an earlier date, Dekker, De Grip and Heijke (1988) developed a model for making medium-term forecasts of employment ('expansion demand') for 82 occupational classes in 22 sectors of industry. The results of those forecasts are to be distributed among types of education with the help of the educational model now being developed.

In the present working document, the educational model is specified by defining each occupation's share in the employment of an industrial sector. The share each type of education has in employment by occupation within an industrial sector is explained in two steps. The first step serves to explain the share which each levels of education has in employment by occupation within an industrial sector. The second step subsequently explains the shares which the various disciplines within each level of education hold in employment by occupation and industrial sector.

Contrary to the traditional Manpower-Requirements approach we will not assume permanent relations between occupations and types of education. As in some earlier studies (ANTOS 1984, NEI 1986, De Grip 1987), we shall assume a somewhat more flexible relationship. Another difference with traditional models is that we shall try to find explanatory variables for the changes in the employment shares of levels of education, and pool the data over occupational classes, sectors of industry, and time.

The working document is organised as follows. Chapter 2 takes up the factors which from economic literature are likely to influence the educational structure of occupational classes within sectors of industry. In chapter 3, a functional form for the educational model is selected. Chapter 4 presents the data employed and the estimation results. Chapter 5 draws some conclusions and briefly evaluates the educational model. 
2. THE EDUCATIONAL MODEL

\subsection{Classification of types of education and occupations}

The ROA information system of education and labour market distinguishes only a limited number of sectors of industry, occupational classes and types of education. The classes of industry have been combined to the 22 sectors used in the sectoral forecasts of the Central Planning Bureau. The occupations have been arranged in 83 occupational classes (classified by the first two digits of the CBS classification).

This working document uses the same division into industrial sectors and occupational classes as in the occupational model, thus ensuring the envisaged correspondence between the two models. For the division into occupational classes (henceforward to be called 'occupations'), see Dekker, De Grip and Heijke (1988).

The types of education distinguished by the first three digits of the SOIclassification have been grouped into 59 educational categories, which we will continue to indicate as types of education. They can be distinguished by level and discipline. The levels are indicated by the first digit of the original SOI-code, running from 2 (Elementary Education) to 6 (Scientific Education). The discipline is indicated by the second and third digits of the same code. The number of disciplines distinguished within a level of education varies from 11 (MAVO = Secondary general education, lower level; LBO = junior vocational education) to 17 (Higher Vocational Education); elementary education contains only one general category, however. Examples of disciplines are the general, technical, and medical disciplines. Annex 4 gives a survey of all types of education we have distinguished. Among the existing types there are some which are difficult to accommodate in the 59 categories we have distinguished. We have combined these to a residual group whose development is assumed to be constant, and which may therefore be left out of the analyses.

\subsection{Technological development and displacement}

We have tried to draw up the educational model in such a way that the employment prospects of persons with a given education can be explained from technological development and the displacement processes on the labour market. 
That technological advance can play an important role in the changing educational structure of an occupation within a sector is obvious. For one thing, with technological progress may come higher educational demands on new staff recruited for certain occupations or in certain industrial sectors. In that event, the functions involved, particularly those which require working with the new technology, are said to be upgraded. For another, mechanisation and automation have been directed - particularly in the last decade - towards replacing low-skilled, routine actions, thus saving on low-skilled labour. By contrast, in some occupations or industrial sectors technological progress may increase the demand for lower-educated manpower, because the higher-skilled tasks are split up and routinised. In that case, downgrading is the proper term.

So, the final effect of technological progress cannot be assessed unequivocally in advance (see also Spenner 1985). We shall include technological advance explicitly in our model, without making a priori statements about the expected development.

As criteria of technological advance in a sector we will use two regressors:

- capital intensity, measured as the ratio between the sector's investments and value added;

- the degree of automation.

The latter is of course related to the former, but especially for the service sectors might be the better indicator of technological change. Unfortunately, however, no exact data are available about the degree of automation in those sectors distinguished by us for which short-term forecasts are available. Investments by sector of industry comprise those in automation, but we have no information about the latter's share. Therefore, we have taken the number of automation experts (occupation class 08) employed in a sector as indicator of its degree of automation or computerisation, and included it as such in the educational model as a regressor.

However, shifts in the educational structure of occupations may also be initiated by supply factors. In an easy labour market, for instance, the competition for jobs may be such that the higher qualified displace the lower skiled from their 'occupational territory'. The process is called downward displacement (see Thurow 1975), and described even more aptly by 
Blaug as 'bumping down' (De Grip 1987). The result is that persons with a high level of education occupy functions previously held by persons with a lower level. Typically, this type of displacement is a one-way process: only persons with a higher level of education are able to push the lower-skilled from of their jobs.

Economists may prefer the (neo)-classical procedure, by which the phenomenon of displacement is described with the help of the relative scarcity of a certain level of education as expressed in the relative wages (see also Centraal Planbureau, 1987). However, for lack of adequate information about the wages earned by persons with a given education, we will have to resort to an approximation. The assumption is warranted that a relatively generous share of a given level of education in the potential labour force will correspond with a relatively generous supply of that category of labour on the labour market. The price of such labour will be relatively low and, ceteris paribus, the persons involved will be put to work more than others (in new occupations and sectors). The difference with the hypothesis of downward displacement is that, while the latter only accommodates displacement of the lower-skilled by the higher-skilled, the neoclassical approach also recognises the possibility of the lower educated replacing the higher educated.

Despite the use of strongly aggregated data we will try to include explicitly in the model the phenomena just described as variables explaining the shifting educational structure of occupations. To that effect we shall follow the Central Planning Bureau (1987) in adding the share of persons with a given level of education in the total potential labour force as third regressor to our model. To distinguish it from the variable generated by technological developments (demand factor), we will refer to the third regressor as 'displacement variable', even though it is evidently not a displacement variable in the narrow sense, but rather an attempt at modelling substitution processes set in motion by supply factors. 


\section{THE ECONOMETRIC SPECIFICATION OF THE MODEL}

\subsection{Introduction}

As pointed out in the introductory section, two steps are needed to relate employment by occupation to employment by type of education. The employment shares of levels of education will be assessed first, and next for each level the shares by discipline. The split approach has been chosen because the required level of education is probably determined by other criteria than the required discipline. We cannot know in advance, however, which has to be determined first: the required level or the required discipline. For reasons of estimation technique we have chosen to explain the level of education as the first step: there are only six different levels against a maximum of 17 different disciplines. In this way the initial number of shares to be broken down further is kept low. In the second step, the shares of the different disciplines within a level of education will be explained.

\subsection{Employment shares by level of education}

As said above, the first step is to explain the shares of the various levels of education in the occupations within industrial sectors. To that end a model is used which takes the absolute volume of employment by occupation and industrial sector as given, the dependent variable being the share which a level of education takes up in the employment of an occupation within a sector. Following the approach used for the educational model (see Dekker, De Grip and Heijke, 1988), we use a multiplicative specification:

$$
\begin{aligned}
O_{k i j t}= & \operatorname{cons}_{k} * P L F_{k t} \alpha_{k} * I N V V A_{j t} \beta_{k} * A U T_{j t} K_{k} * \\
& \exp \left[\gamma_{k i} g_{j}\right] * \exp \left[u_{k i j t}\right]
\end{aligned}
$$

$i=1 . .82, k=2 . .6, j=1 . .22, t=1 . .4$

in which:

$O_{k i j}=E_{k i j} / E_{i j}=$ the proportion of $k$-level workers (E) in the total number of persons employed in occupation $i$ within sector $j$

$\mathrm{PLF}_{k}=$ the relative share of educational level $k$ in the potential labour force 
INVVA $_{j}=$ investments in sector $j$ divided by value added in sector $j$

AUT $_{j}=$ the proportion of automation experts in employment in sector $j$

$\mathrm{t} \quad=\operatorname{year}(1979,1981,1983,1985)$

$g_{1} . .82$ = occupations dummy, $g_{j}=1$ if the observation refers to occupation $i$

$u_{k i j t}=$ disturbance term (normally distributed with expectation 0 ) 1 .

According to equation 3.1, the share of educational level $k$ in the employment of a given occupation $i$ within sector $j$ is determined by $a$ constant term, the share of this educational level in the potential labour force (the substitution variable), the investments by unit of value added in sector $j$, and the share of automation experts in this sector's employment (the technology variables) ${ }^{2}$. We use dummy variables for the various occupations to take account of differences among them not expressed in the exogenous variables mentioned.

The above equation can be linearised by taking the logarithm:

In $O_{k i j t}=$ cons $_{k}{ }^{\prime}+\alpha_{k}$ In PLF $k t+\beta_{k}$ In INVVA I $_{j}+k_{k}$ In AUT $j t$

$$
+v_{i k} g_{i}+u_{k i j t}
$$

$i=1 . .82, k=2 . .6, j=1 . .22, t=1 . .4$

An initial problem encountered in estimating is that equation 3.2 has to be estimated for each of the five educational levels $(k=2 . .6)$, while the shares must add up to 1 . With 6 equations for 5 shares to be estimated, the model is indeed overidentified. In principle, there are two solutions for that problem:

a. To estimate the shares for four levels, leaving the fourth unestimated. One snag of this so-called linear probability model is that no parameter values are found for the influence of the exogenous variables on the remaining level. Another is that there is no guarantee for the share of the non-estimated level to remain positive.

b. To relate the shares to a reference level. In that case the model is called a distribution model. All equations contain the same regressors,

1. We will look closer at the variance of this disturbance term later on.

2. The exact content and construction of the exogenous variables will be dealt with in the next section. 
but with different parameters. When such a model is estimated, the parameters of each educational level are estimated in relation to those of the reference level. The drawback with this solution is that (in this specific case) the parameter for PLF of the reference level has to be set, because PLF, unlike the other regressors, changes with the level of education. Besides, on the reference level no direct effect of the exogenous variables can be assessed with this model either. The advantage of this solution is, however, that the shares of levels remain both below 1 and positive. For the estimation, a model analogous to Parks's multinomial logit model can be used, as was done by the Central Planning Bureau (1987). A disadvantage is that a shock in the development of the reference level occasions an inverse shock on all other levels.

Actually, a distribution model is no feasible proposition in our case, because from the data no educational level can be found that occurs in all cells of the datamatrix. So, only the linear probability model (equation 3.2) can be estimated. On the other hand, the combination of a multiplicative model with a linear probability model is not a very good choice either, because in that case a linear probability model is not consistent (see annex 2). The implication is that for an adequate forecast of the employment shares, the shares will have to be normalised afterwards to make them add up to 1 .

The assumption is that the effect of the exogenous variables on the development of the employment shares of a certain level of education is the same for all occupations and sectors. For each occupation a dummy is indeed included to account for a constant element in the differences between the employment shares of different occupations within a sector. Moreover, the effect of exogenous variables may vary in sense and intensity from one level of education to another.

\subsection{Employment shares by educational discipline}

A simple specification is used to determine the share of each discipline in the employment of a given occupation within a certain sector by a constant term and a trend term. No explanatory variables have been introduced because there is no complete clarity about the processes involved in the explanation of the share of the various disciplines in the employment of a given level of education within an occupation. In principle processes could be assumed 
similar to those modelled in the first step, and the corresponding exogenous variables specified, but in practice that is not feasible for lack of data by discipline. The constant term has been broken down into a general, an occupation-specific, and a sector-specific constant. The specification is as follows:

$R_{1 i j k t}=$ cons $_{1} * \exp \left[\gamma_{1 j} g_{j}\right] * \exp \left[\delta_{1 j} d_{j}\right] * \exp \left[\tau_{1 j} t\right] * \exp \left[v_{1 i j k t}\right]$

$1=1 . .17, i=1 . .82, j=1 . .22, k=2 . .6, t=1 . .4$,

in which:

$R_{1 j j k t}=E_{1 j j k t}=$ share of people of discipline 1 employed in occupation 1 , sector $j$, and educational level $k$ at time $t$

$g_{1 . .83}=$ occupation dummy, $g_{j}=1$ if the observation refers to occupation $i$

$d_{1} .22=$ sector dummy, $d_{j}=1$ if the observation refers to sector $j$

$\mathrm{t}=$ trend term $(1979,1981,1983,1985)$

$v_{1 i j k t}=$ (normally distributed) disturbance term with expectation 0

This equation can be linearised by taking the logarithm:

$\ln R_{1 i j k t}=$ cons $_{1}{ }^{\prime}+\gamma_{1 i} g_{j}+\delta_{1 j} d_{j}+\tau_{1 j} t+v_{1 j j k t}$

To the analogy of the first step, we estimate this equation for each discipline.

Modelling in two steps implies that each type of education is split into independent level and disciplinary aspects. In the first step, the level of education is determined. Actually, a certain level sometimes implies certain disciplines, because not all levels have the same disciplines. The shifts in the educational structure in terms of disciplines are therefore additional to the changes in the disciplinary structure already implied in the model of the educational levels.

\subsection{Specification of variables}

This section goes into the details of the construction of the exogenous variables. 
As described in section 2.2, variable PLF (potential labour force) is a measure of the relative supply of a given level of education and thus for the wage relations (at a given demand structure). PLF $k$ (potential labour force with $k$-level of education in year $t$ ) is constructed on the basis of the Labour-Force Censuses, which twice a year break down the population between the ages of 15 and 64 by level of education.

The variable PLF represents the supply effect. Because of the substitution effect described in section 2.2 we expect this variable to have the positive sign, at any rate for the higher educational levels, and its coefficient to rise with the level of education.

We have considered the following alternative specifications of this regressor:

- the share of the next higher level of education;

- the sum of the shares of all higher levels of education;

- the share of the level of education concerned divided by the sum of the shares of the higher levels;

- the share of the level itself divided by the share of the next higher level.

The first two specifications can be regarded as a more explicit modelling of the downward-displacement hypothesis. The variables represent so-called 'passive substitution', working people with a low level of skill carrying the burden of all higher levels.

The problem encountered in estimating the influence of one of the above specifications is that the data vary so little. The values of the variables for the different levels of education show a continuous rising or declining pattern. As a result, the exogenous variable may behave like a trend term, which makes a specific economic interpretation with respect to active or passive substitution hard to find. In that view we have opted for the simpliest specification, namely, the share of the level of education under study.

The variable INVVA is an indication of technological advance in a given sector of industry ${ }^{3}$. The variable represents, for each sector of industry,

3. Unfortunately, for four out of the seven service sectors no data are available about investment by sector (needed to construct INVTW). The total volume of investment in these four sectors is known, however. We have distributed this total among the four sectors on the basis of value added. The assumption is thus that investment by unit of value added is equal for the four sectors concerned. 
the volume of investment in equipment, transportation, and engineering works in the past five years in relation to the volume of value added in the same period.

$$
\begin{aligned}
& \begin{array}{ll}
0 & 0
\end{array} \\
& I{ }^{N V V A} A_{j t}=\left[\Sigma I N V_{j t+h}\right] /\left[\Sigma \text { TW }_{j t+h}\right] \\
& h=-4 \quad h=-4
\end{aligned}
$$

$I N V_{j t}=$ investments in sector $j$ in year $t$

$T W_{j t}=$ value added in sector $j$ in year $t$

As pointed out in section 2.2, the technological developments in a sector may have consequences for the educational structure in that sector. We expect the upgrading processes to be stronger than the downgrading ones, so that for the study period the coefficient of this variable will have the positive sign for the higher, and the negative sign for the lower levels of education.

Failing direct figures about the degree of automation in the different sectors of industry, we will measure the effect of automation by the share of automation experts in the total number of persons employed within a sector (variable AUT).

AUT $_{j t}=$ Proportion of persons employed in occupation class 08 (= system analysts, statisticiens, mathematiciens and related specialists) in sector $j$ in year $t$.

We have assumed that a large proportion of automatics experts in a sector of industry corresponds with a growing share of the higher educated and a declining share of the lower-skilled, because we expect automation to entail mostly upgrading processes. So, we expect the coefficient of this variable to have the negative sign on the lower levels of education. 


\section{THE ESTIMATION RESULTS}

\subsection{Estimation results by level of education}

To estimate the mode1, we have arranged the data from the original datasets (AKT 1979-85) into cells. A cell is understood here as the combination of a sector of industry and an occupation; its contents represents the number of people employed in a certain occupation in a certain sector of industry. Because the data originate from a sample they can be expected to show heteroscedasticity, which we presume to be associated with the number of working people represented in a cell. We have applied the Goldfeld-Quandt test to find out whether heteroscedasticity occurs with unweighted regression (see, among others, Judge 1982). For this test the assumption is that observations can be arranged by increasing variance. From the outcomes, the zero hypothesis (no heteroscedasticity) must indeed rejected (see annex 1).

Because in our sample 150 employed persons stand for approximately three persons in the original dataset, the values of very small cells are likely to be highly fortuitous. For that reason we shall leave all cells of fewer than 150 persons out of the analysis. In addition, we shall weight the remaining observations with the logarithm of the number of employed in a cell to make that observations with more persons count heavier. The effect of the logarithmic weight becomes less as the cell is larger, so that for large cells the difference in weight is not great. Moreover we believe that weighting with the logarithm of the number of persons in a cell rather than with that number as such provides a reasonable correction for heteroscedasticity.

Table 1 shows the estimation results. The following comments are in order. The parameters of the variable in PLF all have the positive sign, one cause being the separate estimation of the equations. Therefore, the parameter values need to be considered in their mutual relationship. The parameter for the lowest level appears to have the largest positive value (contrary to our expectation, but analogous to the results of the Central Planning Bureau 1987). The high value found is probably due to the simultaneous decline of this level's share in the (potential) labour force (PLF) and the proportion of employed with this level of education. The parameter can still be interpreted as a downward displacement effect, because a declining 
proportion of the lowest-skilled in the potential labour force, which is tantamount to a rising proportion of high-skilled persons, entails a more than proportional decline of the proportion of low-skilled persons in employment.

Table 1. Estimation results of step 1: employment shares by level of education

\begin{tabular}{|c|c|c|c|c|c|}
\hline & level 2 & level 3 & level 4 & level 5 & level 6 \\
\hline In PLF & $\begin{array}{c}1.230 \\
(11.15)\end{array}$ & $\begin{array}{r}0.613 \\
(1.65)\end{array}$ & $\begin{array}{r}0.946 \\
(8.23)\end{array}$ & $\begin{array}{r}0.626 \\
(3.28)\end{array}$ & $\begin{array}{c}0.568 \\
(2.19)\end{array}$ \\
\hline In INVVA & $\begin{array}{r}-0.057 \\
(-4.12)\end{array}$ & $\begin{array}{r}-0.043 \\
(-4.36)\end{array}$ & $\begin{array}{c}0.014 \\
(1.54)\end{array}$ & $\begin{array}{r}0.034 \\
(2.06)\end{array}$ & $\begin{array}{c}0.083 \\
(3.31)\end{array}$ \\
\hline In AUT & $\begin{array}{r}-0.036 \\
(-5.50)\end{array}$ & $\begin{array}{l}-0.012 \\
(-2.41)\end{array}$ & $\begin{array}{r}-0.007 \\
(-1.46)\end{array}$ & $\begin{array}{r}-0.021 \\
(-2.36)\end{array}$ & $\begin{array}{c}0.0002 \\
(0.01)\end{array}$ \\
\hline F-value & 63.47 & 37.97 & 31.88 & 52.42 & 39.68 \\
\hline $\mathrm{R}^{2}$ & 0.700 & 0.536 & 0.485 & 0.712 & 0.766 \\
\hline
\end{tabular}

(t-values in brackets)

Source: ROA.

The parameter values of the variables in INVVA and in AUT, too, should be considered in their mutual relationship. In accordance with our expectations, the parameter values of in INVVA are lower for the lowest levels of education than for the higher levels. The conclusion may be, then, that employment for low-skilled workers is negatively affected by the introduction of new technology. With in AUT, the variable representing the degree of automation in a sector, we also find a stronger negative effect for the lowest than for the highest levels of education. So, with intensified automation, employment for the higher levels of education tends to increase at the expense of the lower levels.

\subsection{Estimation results by discipline}

In the second step, equation 3.4 is estimated for all disciplines. This model contains no explanatory variables but only a trend term and dummies for each level of education, occupation, and sector of industry. When the trend term yields no significant parameter it is set at zero. In view of the 
large number of regressions (59, each with some 105 estimated coefficients), we will not completely represent all estimation results. For each equation estimated, Annex 3 gives the coefficient of the trend variable, the F-values of the sector dummies and the occupation dummies, the number of observations, and the F-values and R-squares. To judge from the R-squares of the equations, the estimation results appear to give a reasonable description of the employment structure by type of education. Some types of education appear to develop according to a strong trend ( $>10$ per cent). A fast declining trend was found with junior medical schools, lower business education, courses for driving instructors, sports coaches, etc. 4. A fast rising trend is found with: junior transport and communication schools, training for the café establishment license, and the university study fields of business administration (ir), econometrics, and actuary. Remember that these are trend-wise developments additional to the development of the employment shares of the educational levels concerned. The two developments may either compensate or reinforce each other.

4. This declining trend is probably largely due to the abolition of the specific training for infant-school teachers. 


\section{CONCLUSIONS}

In this study we have specified an educational model in the form of employment shares by occupation within a sector of industry. These employment shares have been explained in two steps. In the first step, the shares of the various levels of education in employment by occupation and sector are explained, explanatory variables being the relative labour supply (substitution variable), capital intensity, and the degree of automation (technology variables). In the second step, the shares of the various disciplines within a level of education in employment by occupation and sector of industry are explained.

The estimation outcomes of the educational model confirm largely our expectations with respect to the exogenous variables. In particular for the first step the results seem plausible enough. The technology variables are almost invariably significant, and their sign is in accordance with our expectations. The outcomes of the second step cannot be interpreted instantiy, but from annex 3 , they appear to give an adequate picture of the discipline structure of types of education, so that the model gives a reasonably accurate description of reality.

While producing plausible results, the model used so far does show several deficiencies. We need to try in particular for a model which, despite numerous missing cells, still accounts for the relationship between the various levels and disciplines of education as well as the specific structure of the disturbance term (consisting of one component because of the sample data and another because of misspecification).

With hindsight we might comment that the split-up into two separate steps has not been particularly useful, since no explanatory variables have been used to explain the disciplines. Probably, integration of the two steps would not lead to loss of information.

For lack of a reference level for the educational model, we have not used a multinomial logit model. The specification chosen does have the disadvantage that it gives no heed to the connection between the levels.

The introduction might be considered of a more fluctuating supply variable than the potential labour force, such as the outflow from schools or the changes in it. 


\section{LITERATURE}

ANTOS, De arbeidsmarkt naar sector, beroep en opleiding, 1983-1988, Verkennende studie van de werkgroep Anticiperend Opleidings- en Scholingsbeleid (ANTOS), Ministerie van Sociale Zaken en Werkgelegenheid, Den Haag, 1984.

Centraal Bureau voor de Statistiek, Arbeidskrachtentelling, Voorburg, 1979, $1981,1983,1985$.

Centraal Planbureau, De arbeidsmarkt naar opleidingscategorie 1975-2000, werkdocument no. 17, Den Haag, 1987.

Dekker, R.J.P., A. de Grip, J.A.M. Heijke, Een verklaring van de beroepenstructuur van bedrijfstakken, ROA-W-1988/2, Maastricht, 1988.

Grip, A. de, Onderwijs en Arbeidsmarkt: Scholingsdiscrepanties, VUuitgeverij, Amsterdam, 1987.

Grip, A. de, L.F.M. Groot, J.A.M. Heijke, Clustering Occupational Classes by Educational Structure, ROA-W-1987/2E, Maastricht, 1987.

Grip, A. de, J.A.M. Heijke, R.J.P. Dekker, L.F.M. Groot, De arbeidsmarkt naar beroep in 1992 en de positie van academici daarbinnen, ROA-W$1987 / 1$, Maastricht, 1987.

Heijke, J.A.M., Het Researchcentrum voor Onderwijs en Arbeidsmarkt, ROA-R1986/1, Maastricht, 1986.

Judge, G.G. et al., Introduction to the theory and practice of econometrics, Wiley, New York, 1982.

NEI, Een verkenning van de arbeidsmarkt naar beroep en opleiding tot 1990, OSA-werkdocument $\mathrm{nr}$. W17, Zoetermeer, 1986.

Parks, R.W., On the estimation of multinomial logit models from relative frequency data, Journal of Econometrics, vol.13, 1980, pp. 293-303.

Spenner, K.I., The upgrading and downgrading of occupations, Review of Educational Research, vol. 55, no. 2, 1985, pp. 125-154.

Thurow, L.C., Generating Inequality, MacMillan, New York, 1975. 
ANNEX 1: HETEROSCEDASTICITY

For the Goldfeld-Quandt test we proceed as follows. Of the total of $T$ observations, the middle $r(400)$ observations are left out, to enlarge the differences between the two remaining groups. Separate regressions are carried out on the first and last $(T-r) / 2$ observations. The result S1/S2 (the sum of residual squares of the regression on the first observations divided by the second sum of squares) now follows an F-distribution with $[(T-2-2 k) / 2,(T-r-2 k) / 2]$ degrees of freedom, with $k$ regressors.

With our model we arrange the observations by the number of employed in the cells. We expect observations with few people in the cell to have the widest variance. We use the first and last 1175 observations to find F-value $682.38 / 225.13=3.03 \gg 1.53=F[120,120]$. The null hypothesis $H_{0}: \sigma_{t}=\sigma$ (meaning that the variance is independent of the size of the cell) is rejected, so that heteroscedasticity is likely to occur. Omitting observations with fewer than 150 persons in a sector-occupation combination, we are left with 2160 observations, of which the middle 160 are left out of account. The sample statistic now is $421.98 / 132.36=3.19$. Again the null hypothesis (no heteroscedasticity) is rejected. Apparently, even after omission of very small cells heteroscedasticity remains probable.

With the other levels of education, too, we find that the null hypothesis (no heteroscedasticity) is rejected. 
ANNEX 2: THE INCONSISTENCY OF A MULTIPLICATIVE DISTRIBUTION MODEL

The reference to a normative category being abandoned in our model, our system of equations is no longer consistent.

We give an example with three levels of education:

In $0_{1 i j t}=$ cons $_{1}+\alpha_{1}$ In PLF $1 t+\beta_{1}$ In INVVA $j t+\gamma_{i 1} g_{i}+u_{1 i j t}$

ln $0_{2 i j t}=$ cons $2+\alpha_{2}$ In PLF $2 t+\beta_{2}$ In INVVA $j t+\gamma_{i 2} g_{j}+u_{2 i j t}$

$\ln 0_{3 i j t}=$ cons $3+\alpha_{3}$ In PLF $3 t+\beta_{3}$ In INVVA $j t+\gamma_{i 3} g_{j}+u_{3 i j t}$

Because the initial shares have to add up to 1 ( $\left.p_{0} d_{0}\right)$, for the above system the condition holds that the logarithms of the sums of shares have to add up to 0 . As a consequence, the right-hand terms too are subject to certain conditions. Because we have not imposed these conditions while estimating such a system, the odds are that the estimation outcomes do not satisfy them either. 
ANNEX 3: ESTIMATION RESULTS OF THE SECOND STEP

\begin{tabular}{|c|c|c|}
\hline OPL & $=$ & discipline (see annex 4 ) \\
\hline F-VALUE & $=$ & $\begin{array}{l}\text { test quantity for the significance of the equation as a } \\
\text { whole (with only a constant term as null hypothesis) }\end{array}$ \\
\hline F-TAK & $=$ & $\begin{array}{l}\text { test quantity for the significance of the dummies for } \\
\text { the sectors of industry (with one constant term for all } \\
\text { sectors as null hypothesis) }\end{array}$ \\
\hline F-BEROEP & $=$ & $\begin{array}{l}\text { test quantity for the significance of the dummies for } \\
\text { the occupations (with one constant term for all } \\
\text { occupations as null hypothesis) }\end{array}$ \\
\hline $\mathrm{T}$ & $=$ & coefficient of the trend term \\
\hline & $=$ & number of observations used in estimating this equation \\
\hline
\end{tabular}

Table 2. Estimation results of step 2: employment shares by type of education

\begin{tabular}{|c|c|c|c|c|c|c|}
\hline & $T$ & F-TAK & F-BEROEP & F-VAIUE & R2 & $\begin{array}{l}\text { NUMBER OF } \\
\text { OBSERVATION }\end{array}$ \\
\hline
\end{tabular}

\begin{tabular}{|c|c|c|c|c|c|c|}
\hline 2 & $\begin{array}{c}0,024^{\star} \\
(2,09)\end{array}$ & $4,05^{*}$ & $31,68^{*}$ & $29.05^{*}$ & 0,649 & 1690 \\
\hline 3 & $\begin{array}{r}0,056 \\
(1,93)\end{array}$ & $3,94^{*}$ & $14,59^{*}$ & $14,93^{*}$ & 0,656 & 795 \\
\hline 4 & $\begin{array}{c}-0,035^{*} \\
(-3,43)\end{array}$ & $7,45^{*}$ & $54,39^{*}$ & $51,30^{*}$ & 0,762 & 1689 \\
\hline 5 & $\begin{array}{l}0,128^{*} \\
(2.71)\end{array}$ & $6,86^{*}$ & $7,18^{*}$ & $8,67^{*}$ & 0,686 & 394 \\
\hline 6 & $\begin{array}{c}-0,366^{*} \\
(-2,55)\end{array}$ & 2,27 & 2,18 & $3,05^{*}$ & 0,810 & 85 \\
\hline 7 & $\begin{array}{l}-0,105^{*} \\
(-5,33)\end{array}$ & $3,20 *$ & $12,92^{*}$ & $11,82^{*}$ & 0,523 & 1189 \\
\hline 9 & $\begin{array}{r}0,389 \\
(1,21)\end{array}$ & 1,19 & 2,37 & $2,18^{*}$ & 0,779 & 77 \\
\hline 10 & $\begin{array}{r}0,006 \\
(0,31)\end{array}$ & $9,03^{*}$ & $23,82^{*}$ & $21,36^{*}$ & 0,674 & 1053 \\
\hline 11 & $\begin{array}{c}0,428^{*} \\
(3,68)\end{array}$ & $5,66^{*}$ & $5,73^{*}$ & $8,65^{*}$ & 0,902 & 90 \\
\hline 12 & $\begin{array}{r}0,136 \\
(1,25)\end{array}$ & $4,06^{*}$ & $10,82^{*}$ & $9,87^{*}$ & 0,901 & 95 \\
\hline 13 & $\begin{array}{r}0,056 \\
(0,15)\end{array}$ & 0,90 & 1,14 & 1,37 & 0,732 & 28 \\
\hline
\end{tabular}




\begin{tabular}{|c|c|c|c|c|c|c|}
\hline 14 & $\begin{array}{l}-0,035^{\star} \\
(-2,05)\end{array}$ & $5,77^{*}$ & $20,05^{*}$ & $18,68^{*}$ & 0,584 & 1458 \\
\hline 15 & $\begin{array}{l}-0,102^{*} \\
(-2,06)\end{array}$ & $3,15^{*}$ & $7,29^{*}$ & $7,54^{*}$ & 0,653 & 402 \\
\hline 17 & $\begin{array}{l}-0,042 \\
(-1,29)\end{array}$ & $10,45^{*}$ & $14,59^{*}$ & $17,65^{*}$ & 0,716 & 746 \\
\hline 18 & $\begin{array}{r}0,010 \\
(0,16)\end{array}$ & $3,93^{*}$ & $12,34^{*}$ & $12,58^{*}$ & 0,841 & 210 \\
\hline 19 & $\begin{array}{l}-0,057^{\star} \\
(-4,63)\end{array}$ & $17,87^{*}$ & $56,00^{*}$ & $55,80^{*}$ & 0,767 & 1831 \\
\hline 20 & $\begin{array}{l}-0,068^{*} \\
(-2,08)\end{array}$ & $22,23^{*}$ & $12,51^{*}$ & $18.68^{*}$ & 0,715 & 735 \\
\hline 21 & $\begin{array}{l}-0,091^{*} \\
(-2,15)\end{array}$ & $8,86^{*}$ & $6,35^{*}$ & $10,06^{*}$ & 0,687 & 459 \\
\hline 22 & $\begin{array}{l}-0,021 \\
(-0,30)\end{array}$ & $3,41^{*}$ & $5,23^{*}$ & $5,55^{\star}$ & 0,654 & 265 \\
\hline 23 & $\begin{array}{r}0,113 \\
(0,81)\end{array}$ & $5,55^{*}$ & $4,68^{*}$ & $5,42^{*}$ & 0,801 & 62 \\
\hline 24 & $\begin{array}{l}-0,073 \\
(-1,20)\end{array}$ & $5,71^{*}$ & $6,73^{*}$ & $9,05^{*}$ & 0,771 & 219 \\
\hline 25 & $\begin{array}{c}0,045^{*} \\
(3.35)\end{array}$ & $11,26^{*}$ & $40,03^{*}$ & $36,13^{*}$ & 0,694 & 1727 \\
\hline 26 & $\begin{array}{l}-0,074 \\
(-1,42)\end{array}$ & $9,56^{*}$ & $5,80^{*}$ & $9,10^{*}$ & 0,692 & 385 \\
\hline 27 & $\begin{array}{l}-0,035 \\
(-0,76)\end{array}$ & $3,56^{*}$ & $9,83^{*}$ & $8,98^{*}$ & 0,696 & 390 \\
\hline 28 & $\begin{array}{l}-0,035 \\
(-1,23)\end{array}$ & $7,93^{*}$ & $15,28^{*}$ & $14,82^{*}$ & 0,668 & 754 \\
\hline 29 & $\begin{array}{l}-0,088 \\
(-1,79)\end{array}$ & $3,91^{*}$ & $12,14^{*}$ & $12,01^{*}$ & 0,751 & 385 \\
\hline 30 & $\begin{array}{r}0,021 \\
(0,10)\end{array}$ & 1,78 & 1,82 & $2,72^{*}$ & 0,863 & 64 \\
\hline 31 & $\begin{array}{l}-0,085^{*} \\
(-2,12)\end{array}$ & $7,78^{*}$ & $10,19^{*}$ & $10,78^{*}$ & 0,656 & 614 \\
\hline 32 & $\begin{array}{l}-0,151^{*} \\
(-6,78)\end{array}$ & $4,45^{*}$ & $11,78^{*}$ & $10,58^{*}$ & 0,609 & 655 \\
\hline 33 & $\begin{array}{l}-0,218^{*} \\
(-2,34)\end{array}$ & $2,16^{*}$ & $2,13^{*}$ & $2,35^{*}$ & 0,564 & 128 \\
\hline 34 & $\begin{array}{l}-0,063 \\
(-0,66)\end{array}$ & 2,57 & $33,71^{*}$ & $27,42^{*}$ & 0,963 & 40 \\
\hline 35 & $\begin{array}{l}-0,037 \\
(-0,79)\end{array}$ & $7,76^{*}$ & $9,25^{*}$ & $13,46^{*}$ & 0,812 & 240 \\
\hline 36 & $\begin{array}{l}-0,003 \\
(-0,06)\end{array}$ & $3,98^{*}$ & $13,94^{*}$ & $12,38^{*}$ & 0,774 & 306 \\
\hline
\end{tabular}


$-20-$

\begin{tabular}{|c|c|c|c|c|c|}
\hline 37 & $\begin{array}{l}-0,039 \\
(-1,55)\end{array}$ & $12,42^{\star}$ & $16,41^{*}$ & $21,21^{*}$ & 0,737 \\
\hline 39 & $\begin{array}{l}-0,091^{*} \\
(-2,50)\end{array}$ & $11,99^{*}$ & $9,82^{*}$ & $15,07^{*}$ & 0,765 \\
\hline 40 & $\begin{array}{l}-0,115 \\
(-1,67)\end{array}$ & $7,22^{*}$ & $7,98^{*}$ & $8,11^{*}$ & 0,791 \\
\hline 41 & $\begin{array}{l}-0,006 \\
(-0,09)\end{array}$ & $6,75^{*}$ & $8,20^{*}$ & $8,10^{*}$ & 0,779 \\
\hline 43 & $\begin{array}{l}-0,023 \\
(-0,12)\end{array}$ & 0,80 & $3,31^{*}$ & $3,22^{*}$ & 0,770 \\
\hline 44 & $\begin{array}{c}0,058^{*} \\
(2,54)\end{array}$ & $6,26^{*}$ & $27,24^{*}$ & $23,77^{\star}$ & 0,751 \\
\hline 45 & $\begin{array}{l}-0,023 \\
(-0,26)\end{array}$ & $5,28^{*}$ & $5,56^{*}$ & $6,04^{*}$ & 0,751 \\
\hline 46 & $\begin{array}{r}0,026 \\
(0,50)\end{array}$ & $2,62^{*}$ & $13,00^{*}$ & $10,22^{*}$ & 0,784 \\
\hline 47 & $\begin{array}{l}-0,001 \\
(-0,02)\end{array}$ & $3,02^{*}$ & $12,14^{*}$ & $9,32^{*}$ & 0,651 \\
\hline 49 & $\begin{array}{l}-0,107 \\
(-1,33)\end{array}$ & $4,04^{*}$ & $9,29^{*}$ & $11,23^{*}$ & 0,880 \\
\hline 50 & $\begin{array}{l}-0,106^{*} \\
(-2,40)\end{array}$ & $4,55^{*}$ & $17,08^{*}$ & $16,50^{*}$ & 0,852 \\
\hline 51 & $\begin{array}{r}0,153 \\
(1,34)\end{array}$ & 2,07 & $6,24^{*}$ & $4,33^{*}$ & 0,761 \\
\hline
\end{tabular}

$52 \begin{array}{llllll}-0,050 & 2,69^{*} & 21,63^{*} & 15,01^{*} & 0,903 & 87\end{array}$

$\begin{array}{lllllll}53 & -0,080 & 2,65^{*} & 9,31^{*} & 8,27^{*} & 0,785 & 109 \\ & (-1,23) & & & & & \\ 54 & -0,169 & 2,13 & 14,28^{*} & 14,83^{*} & 0,905 & 47 \\ & (-1,62) & & & & & \end{array}$

$\begin{array}{lllllll}55 & 0,016 & 1,97 & 7,20^{*} & 5,86^{*} & 0,732 & 108 \\ (0,17) & & & \end{array}$

$\begin{array}{lllllll}56 & -0,055 & 1,57 & 22,38^{*} & 14,21^{*} & 0,773 & 218\end{array}$

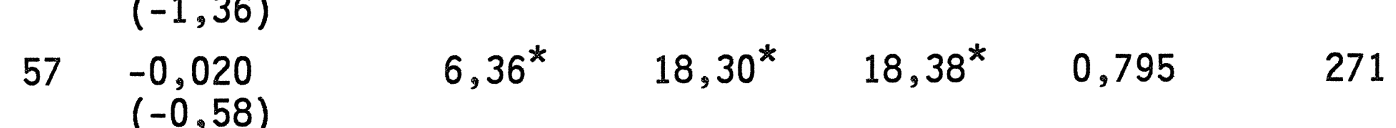

$\begin{array}{llllll}58 & -0,011 & 5,15^{*} & 7,10^{*} & 7,01^{*} & 0,762\end{array}$

$59 \begin{array}{llllll}(-0,11) & & & \\ -0,223 & 10,68^{*} & 3,95^{*} & 8,14^{*} & 0,872 & 45\end{array}$

$\begin{array}{lclllll}60 & \begin{array}{c}-0,047 \\ (-1,08)\end{array} & 3,06^{*} & 23,76^{*} & 15,94^{*} & 0,784 & 233 \\ 61 & \begin{array}{c}0,283^{*} \\ (2,33)\end{array} & 2,90^{*} & 4,86^{*} & 5,58^{*} & 0,763 & 72 \\ 62 & \begin{array}{l}-0,023 \\ (-0,55)\end{array} & 2,73^{*} & 21,30^{*} & 14,79^{*} & 0,831 & 181\end{array}$


$-21-$

$\begin{array}{lllllll}63 & -0,011 & 1,14 & 7,20^{*} & 4,86^{*} & 0,603 & 198 \\ & (-0,18) & & & & & \\ -0,220 & 4,30^{*} & 6,49^{*} & 8,67^{*} & 0,876 & 41 \\ (-1,77) & & & & \end{array}$

( $t$-values in brackets)

(parameters with * are significant on the five-percent level)

Source: ROA 
ANNEX 4: LIST OF TYPES OF EDUCATION

no. SOI title

Leve1 2:

$1201 \quad$ Elementary education

Leve1 3:

2301 General secondary education, pre-university education

3321 Junior agricultural education

4331 Junior technical education

5341 Junior transport, communication and traffic education

$6351 \quad$ Junior medical and paramedical education

$7361 \quad$ Lower business education, Secondary school for tradesmen (lower level), Practical training for clerks and salesmen at the school for domestic science and technique

$9371 \quad$ Athletes' masseur etc., liberal education

10381 School for domestic science and technique exclusive of training for clerks and salesmen

11383 Establishment certificate for café holders

12391 Business security and surveillance training

13398 Cleaning of buildings, sexton's certificate

Level 4:

14401 General Secondary Education, intermediate and higher levels

15406 Training for driving instructor, sports coach

$17421 \quad$ Senior agricultural education

$18431 \quad$ Senior school for laboratory science

$19436 \quad$ Senior technical training

20441 Senior education in transportation, communication and traffic science

21451 Training of nurses and medical receptionists at the secondary school for medical and other services, higher level

22452 Secondary school for medical laboratory science, higher level

23453 Training for medical clerks, etc.

$24454 \quad$ Training for ward orderlies, etc.

25461 Senior retail school and intermediate business education

26466 Intermediate business education, department of management studies 
27471 Social work and welfare work (secondary school for medical and other services)

$28481 \quad$ External care, services as taught at the secondary school for medical and other services or the INTAS

29483 Secondary hotel and catering school, hairdresser's school

$30486 \quad$ Fashion drawing, etc.

31491 Training of municipal and state police, fire brigade

Leve1 5:

32506 Training college for primary and pre-primary school teachers, Secondary-school teacher training, new style

$33511 \quad$ Training for interpreters and translators

$34516 \quad$ Training for pastoral work, etc.

$35521 \quad$ Agricultural college

$36531 \quad$ Laboratory college

$37536 \quad$ Technical college

$39541 \quad$ Transport, communication and traffic college

$40551 \quad$ Nursing college, physiotherapy college

$41552 \quad$ College for medical laboratory science

43554 Dietetics college, etc.

44561 Business science college, exclusive of administrative and fiscal studies

45562 Courses for ergonomists and management science at the Higher Technical School, etc.

$46566 \quad$ Business science college, legal and administrative studies

$47571 \quad$ College of social studies, Library studies

49583 Hotel College

$50586 \quad$ Art Academy, Academy of Dramatic Art

51591 Police College, RMA, Naval Academy

Leve1 6:

52606 Teacher training (highest leve1)

$53611 \quad$ Language and literature

$54616 \quad$ Theology

$55 \quad 621 \quad$ Agricultural and domestic sciences

$56 \quad 631 \quad$ Mathematics and physics

$57636 \quad$ Technical sciences

$58651 \quad$ Medical sciences

$59652 \quad$ Pharmacy 
$-24-$

60661 Economics and business administration (B.A.)

61662 Econometrics, actuary and management (B.SC.)

62666 Law

$63671 \quad$ Socio-cultural sciences

$64686 \quad$ Fine arts 


\section{Publicaties/Publications ROA}

\section{Rapporten/Reports:}

ROA-R-1986/1

ROA-R-1986/1E

ROA-R-1987/1

ROA-R-1987/2

ROA-R-1987/3

ROA-R-1988/1

ROA-R-1988/2

ROA-R-1989/1

ROA-R-1989/2

ROA-R-1989/3

ROA-R-1989/4

ROA-R-1989/4E

ROA-R-1989/5

ROA-R-1989/6
J.A.M. Heijke, Het Researchcentrum voor Onderwijs en Arbeidsmarkt. ISBN 90-5321-001-6

J.A.M. Heijke, The Research Centre for Education and Labour Market. ISBN 90-5321-002-4

A. de Grip, J.A.M. Heijke en L.A. Vos, Inventariserend onderzoek arbeidsmarktmodule I-SEE project. ISBN 90-5321-003-2

Researchcentrum voor Onderwijs en Arbeidsmarkt, Naar een informatiesysteem onderwijs-arbeidsmarkt, onderzoekprogramma 1987/1988. ISBN 90-5321-004-0

A. de Grip, J.A.M. Heijke, R.J.P. Dekker, L.F.M. Groot en L.A. Vos, De arbeidsmarktperspectieven van studierichtingen in het wetenschappelijk onderwijs, Arbeidsmarktmodule I-SEE project. ISBN 90-5321-005-9

Researchcentrum voor Onderwijs en Arbeidsmarkt, Naar een informatiesysteem onderwijs-arbeidsmarkt, onderzoekprogramma 1988/1989. ISBN 90-5321-006-7

A. de Grip, J.A.M. Heijke, J.W. van Dam, R.J.P. Dekker en M.H. Wieling, Aanvulling arbeidsmarktmodule I-SEE project (wetenschappelijk onderwijs). ISBN 90-5321-007-5

Researchcentrum voor Onderwijs en Arbeidsmarkt, Naar een een informatiesysteem onderwijs-arbeidsmarkt, onderzoekprogramma 1989/1990. ISBN 90-5321-008-3

A. de Grip, J.A.M. Heijke, W.J. Nusselder, G.W.M. Ramaekers, Naar een informatiesysteem onderwijs-arbeidsmarkt voor de haven van Rotterdam, verslag vooronderzoek. ISBN 90-5321-009-1

J.W. van Dam, J.A.M. Heijke, G.W.M. Ramaekers, Ontwerp van een arbeidsmarktscanner voor academici . ISBN 90-5321-010-5

A. de Grip, W.J. Nusselder, Technologie-indicatoren met betrekking tot scholing en arbeid. ISBN 90-5321-011-3

fl 22,50

niet voor

publicatie

fl 6,50

fl 27,50

fl 32,50

A. de Grip, W.J. Nusselder, Technology Indicators Referring fl 22,50 to Education and Labour. ISBN 90-5321-026-1

P.J.E. van de Loo, A. de Grip, De positie en aansluiting op de arbeidsmarkt van schoolverlaters van het MBO en Kort MBO in Midden-Limburg. ISBN 90-5321-012-1

fl 35,00

fl 13,50

hoger onderwijs en de arbeidsmarkt: een theoretisch kader. ISBN 90-5321-027-X 
ROA-R-1989/7 A. de Grip, J.A.M. Heijke, R.J.P. Dekker, Th.B.J. Beekman,

niet voor

H.M.M. Peeters, De arbeidsmarktperspectieven van beroeps-

publicatie klassen en opleidingstypen in 1992: rapportage: I-See! ISBN 90-5321-024-5

ROA-R-1989/8 A. de Grip, J.A.M. Heijke, R.J.P. Dekker, De arbeidsmarkt naar beroep en opleiding in 1992. ISBN 90-5321-025-3

fl 22,50

\section{Werkdocumenten/Working Papers:}

ROA-W-1987/1

A. de Grip, J.A.M. Heijke, R.J.P. Dekker en L.F.M. Groot, De arbeidsmarkt naar beroep in 1992 en de positie van academici daarbinnen. ISBN 90-5321-013-X

ROA-W-1987/1E A. de Grip, J.A.M. Heijke, R.J.P. Dekker en L.F.M. Groot, Labour Market Prospects for Occupations and Academic Studies in 1992. ISBN 90-5321-014-8

ROA-W-1987/2E

A. de Grip, L.F.M. Groot and J.A.M. Heijke, Clustering Occupational Classes by Educational Structure. ISBN 90-5321-015-6

ROA-W-1988/1

A. de Grip, J.A.M. Heijke, Arbeidsmarktindicatoren: een inventarisatie. ISBN 90-5321-016-4

ROA-W-1988/1E A. de Grip, J.A.M. Heijke, Labour Market indicators: an inventory. ISBN 90-5321-017-2

ROA-W-1988/2 R.J.P. Dekker, A. de Grip, J.A.M. Heijke, Een verklaring van de beroepenstructuur van bedrijfstakken. ISBN 90-5321-018-0

ROA-W-1988/2E R.J.P. Dekker, A. de Grip, J.A.M. Heijke, An explanation of the occupational structure of branches of industry. ISBN 90-5321-019-9

ROA-W-1988/3 J.W. van Dam, A. de Grip, J.A.M. Heijke, Op zoek naar informatiebronnen over de arbeidsmarktpositie van academici. ISBN 90-5321-020-2

ROA-W-1989/1E L. Borghans, Information and the choice for schooling. ISBN 90-5321-021-0.

ROA-W-1989/2 L.F.M. Groot, J.A.M. Heijke, Een verklaring van arbeidsduur en deeltijdarbeid naar beroep en bedrijfstak. ISBN 90-5321-022-9

ROA-W-1989/3 Th.B.J. Beekman, R.J.P. Dekker, A. de Grip, J.A.M. Heijke, ISBN 90-5321-023-7

ROA-W-1989/3E Th.B.J. Beekman, R.J.P. Dekker, A. de Grip, J.A.M. Heijke, An Explanation of the Educational Structure of occupations. ISBN 90-5321-028-8 fl 17,50

fl 17,50

fl 20,00

fl 15,00

fl 15,00

fl 17,50

fl 17,50

fl 22,50

fl 15,00

fl 17,50

fl 17,50

fl 17,50 


\section{Herdrukken/Reprints:}

nr. 1.

A. de Grip, Causes of Labour Supply and Demand Mismatches

fl 7,00 in the Dutch Building Trades, in: De Economist jrg. 135, nr. 2, 1987, pp. 182-200.

nr. 2

J.A.M. Heijke, The Labour Market Position of Migrants in Selected European Receiving Countries, in: The Future of Migration, OECD, Paris, 1987, pp. 170-209.

nr. 3

J.A.M. Heijke, Internationale migratie en bevolkingsstructuur, in

fl 8,50 Demografische veranderingen en economische ontwikkelingen. Preadviezen aan de Koninklijke Vereniging voor de Staathuishoudkunde 1987, 1987, pp. 125-126.

nr. 4

A. de Grip, Winnaars en Verliezers op de Arbeidsmarkt 1981-1985, fl 5,00 in: Tijdschrift voor Arbeidsvraagstukken, jrg. 3, nr. 4, 1987, pp. 61-69.

nr. 5

J.A.M. Heijke, Arbeidsmarktinformatie voor studie en beroeps-

fl 5,00 keuze, in: Dekanoloog congresbundel, jrg. 25, nr. 1, 1988, pp. 20-22 en 13-14.

nr. 6 J.A.M. Heijke, Arbeidsmarktinformatie en de keuze van studie en beroep, in: Dekanoloog jaarcongres 1988, jrg. 25, nr. 5/6, pp. 155-160.

nr. 7

A. de Grip, J.A.M. Heijke, R.J.P. Dekker, L.F.M. Groot, "De arbeidsmarkt naar beroep in 1992" en "Arbeidsmarktperspectieven van universitaire studierichtingen", in: Economisch Statistische Berichten, 29 juni en 6 juli 1988, 73e jaargang, nrs. 3662 en 3663.

nr. 8

L.F.M. Groot, J.J. Schippers, J.J. Siegers, The effect of interruptions and part-time work on women's wage rate: a test of the variable-intensity model, in: De Economist, 136 nr. 2, 1988 pp. 220-238.

nr. 9

A. de Grip, J.A.M. Heijke, Het flexibiliteitspotentieel van universitaire studierichtingen, in: Tijdschrift voor arbeidsvraagstukken, jrg. 5, 1989 nr. 4, pp. 69 t/m 81. 
